\title{
CITIZEN DESIRES, POLICY OUTCOMES, AND COMMUNITY CONTROL
}

\author{
JOEL D. ABERBACH and JACK L. WALKER \\ Department of Political Science and Institute of Public Policy Studies \\ University of Michigan
}

Reformers have been hard at work in American cities for over a century. Since the middle of the nineteenth century, city governments have been struggling to plan their development, eliminate waste, relieve human suffering, check or at least moderate, the most vicious forms of exploitation, and create humane, responsive agencies of government. The history of these efforts is full of ironies and frustrations. Reformers themselves have frequently clashed over whether the greatest needs of the cities were improved management and more efficiency or new political institutions which would allow individual citizens greater influence over their government, two aims which sometimes directly conflict. Institutional changes of ten have led to outcomes wholly unexpected by those who fought to bring them into being, and the reforms of one era frequently have become the principal weapons of those resisting change in later decades.

AUTHORS' NOTE: We wish to acknowledge the financial assistance of the National Institute of Mental Health, the Committee on Governmental and Legal Processes of the Social Science Research Council, and the National Science Foundation which made this research possible. Thanks are due to 
This essay deals with a recent effort at urban reform, the movement for community control over schools in America's largest cities. The efforts to achieve this goal have caused monumental conflicts in several cities, notably New York, but in the last few years decentralization plans have been accepted in many large cities. These plans differ enormously, however, from those initially proposed by reformers who wanted to force centralized bureaucracies to deal more effectively with the needs of black and chicano students. ${ }^{1}$ An examination of the processes through which these plans were transformed provides insight into the difficulties of making planned changes in American cities. This study will demonstrate that putting theories into practice is as difficult as ever. ${ }^{2}$

The object of this study is the controversy over school decentralization in Detroit, Michigan, during 1969, 1970, and 1971. In September 1971, Detroit's schools began operating under a new, decentralized system, but this came about only after two years of conflict. The outcome of this dispute raises important questions about the nature of decentralization, the future of racial integration, and the role of public opinion and forms of direct democracy in determining the course of public policy. This essay begins with a brief history of the decentralization controversy in Detroit and a report on recent changes in basic attitudes toward racial integration among both blacks and whites. This is followed by an analysis of public attitudes toward decentralization and a description of reactions among both racial groups to the effort to recall several members of the Detroit Board of Education in August 1970, a major event in the decentralization dispute. The paper concludes with a summary of the findings and a discussion of their broader implications.

Douglas B. Neal of the University of Michigan's Institute of Public Policy Studies, who assisted in the data analysis, and the Brookings Institution, which granted both shelter and peace and quiet to Jack L. Walker while portions of this paper were being drafted. An earlier version was delivered at the 1971 Annual Meeting of the American Political Science Association in Chicago, Illinois. 


\section{THE DATA}

This study is based primarily on data collected from newspapers and periodicals and from two surveys of public opinion in Detroit, completed in 1967 and 1971. In the 1967 survey, 855 respondents were interviewed (394 whites and 461 blacks). Approximately 62\% of the respondents in 1967 were chosen in a sample of the households in the entire city; the rest represent a supplementary sample of the zone within the city in which Detroit's 1967 civil disorders took place. In the 1971 survey, 568 respondents were interviewed (394 whites and 174 blacks). A sample of dwelling units, rather than housing units, was used in the 1971 study in hopes of including more renters, single men, and others often missed in sample surveys. In both surveys, white respondents were interviewed by whites, blacks by blacks. ${ }^{3}$

\section{THE SETTING}

\section{THE PLANS AND THE CONTROVERSY}

Detroit, Michigan, along with many other cities, now has a decentralized school system. Eight new regions exist within the district, each of which is presided over by five-member elected boards. The central board of education has thirteen members, eight of whom are representatives from the new regional boards, and five of whom are elected from the citywide district at-large. Regional boards have "responsibilities in personnel, curriculum and budgets under guidelines set by [the] Central Board" (New Detroit Now, 1970). Put this way, the system sounds relatively simple, but the controversy which led to the adoption of this decentralization plan was both involved and bitter.

The controversy began with the passage of the first Detroit decentralization bill (Public Act 244) by the Michigan State Legislature. This bill was introduced by state Senator Coleman Young, a leading black politician, in the spring of 1969. By fall, it was law. There was little opposition or excitement. 
Then came a series of studies and hearings by the Detroit Board of Education on how to implement decentralization. The hearings attracted more spokesmen from the black community for separation than integration. Whites who appeared generally opposed decentralization, but if it had to come, they also expressed a desire for separation. The board had a series of plans drawn up and on April 7, 1970, opted for one which called for 7 local regions and changes in the feeder patterns of 12 of the city's 22 high schools. The goal was to have racially integrated districts of equal population.

The initial changes in school attendance actually required were very small, ${ }^{4}$ but a large storm arose. (Detroit's former Superintendent of Schools, Normal Drachler, at a 1970 lecture at the University of Michigan, attributes part of this passion to the fact that under the plan eventual integration was at least possible.) Some whites, quickly organized into a Citizens' Committee for Better Education, began a petition drive to recall the four board members who supported the plan.

The controversy soon was returned to the state legislature, where the original decentralization bill, passed with so little consideration or debate a year before, was hastily repealed. The principle of decentralization was retained, however, in the new bill (Public Act 49) passed in July 1970, which effectively recalled three of the four board members who supported the integration plan by changing the length of their terms so that they ended in December 1970. Under the new decentralization plan, the governor appointed a boundary commission to design the new regions. These new boundaries were to follow existing school attendance areas as closely as possible and were not to materially affect attendance patterns.

It was thought by legislative leaders "that these actions would serve to stop the recall drive" (Detroit Free Press, $1970 a)^{5}$ but the leaders of the white Citizens' Committee for Better Education decided to pursue their efforts in order to warn future school board members never to resurrect the integration plan. After several legal maneuvers, suits, and countersuits, a three-judge panel of the Michigan State Court of 
Appeals on July 31, 1970 (a Friday), ruled that the recall motion definitely would appear on the August 4 primary ballot, barely four days later. Since this decision left only one weekend for a campaign, the efforts of both sides were limited. The citizens' committee, being better organized, was able to mount a door-to-door weekend campaign in favor of the recall, while the opposition forces were virtually paralyzed.

In the August vote, the recall motion passed by approximately 105,000 to 75,000 , with white districts supporting it heavily and blacks in opposition. Turnout, as in any primary, was low, the recall was at the end of the ballot, and blacks, especially, had a high proportion of blank ballots on the issue.

Reaction to the recall was bitter on the part of school officials committed to integration and the affected board members. One school official said that "The song is "community control' and the tune is 'Dixie" "(Detroit Free Press, 1970b). Recalled member Andrew Perdue lamented, "Where is everybody? Where are the people who helped get us elected-the UAW, the NAACP and the others? Don't they care anymore?" (Detroit Free Press, 1970c; for a more comprehensive review of the entire controversy, see Grant, 1971).

The answers to Perdue's questions are crucial to an understanding of the future of integration in the city and the meaning of decentralization as it is actually put into practice. The newspaper of the black community castigated

those few black citizens who supported the recall movement under the guise of achieving black power over black schools [but] were in reality supporting white racist control of the total community, including its schools... The most disturbing thing about the black voters among the silent majority that permitted the Detroit disgrace on Tuesday, August 4 is their unawareness of the basic issue at stake. The issue was not really desegregation in the high school-unwelcome though that may be in certain sections of our city.

The business of desegregation was only the final straw. The real issue was that the current board, sparked by the four recalled members, put Detroit in the forefront of school systems with integrated teaching staffs and truly integrated administrative staff at the top policy level. 
The real issue was the rapid growth of black power at the controlling levels of the school system. This is what was unforgivable for the four liberal Board members. And this issue the black silent majority completely overlooked [Michigan Chronicle, 1970]. ${ }^{6}$

Detroit is now operating with a so-called "Magnet School" plan which involves the pairing of regions so that there are adequate numbers of black and white students "to make voluntary integration possible"' (Magnet School Plan, 1971). In each pair of regions, at least four high schools offer specialized programs to attract interested students. Admission preference is given to racial transfers in order to maximize integration. Students, of course, may simply remain in their home school if they wish (all high schools will retain comprehensive programs). Each region has also established an experimental and superior middle school (grades 5-8) designed to attract an integrated student body.

\section{BASIC ATTITUDES TOWARD RACIAL INTEGRATION}

Although a majority of the blacks who voted were opposed to the recall of the school board members, both the turnout and the margin of victory in black neighborhoods was disappointing to the advocates of racially integrated education. There was obviously considerable confusion among black voters over this issue, evidenced by the "curious absence of campaigning"? noticed by several observers, and by the fact that in some areas almost half the black voters simply neglected to mark their ballots on the recall question. ${ }^{8}$ There were many factors contributing to this electoral outcome, and the surveys we have conducted in Detroit in 1967 and 1971 provide some insight into the problems. Our interviews dealt with attitudes of blacks and whites toward racial integration, and were designed to help explain the behavior of leaders and followers on both sides of this controversy.

In order to discover respondents' attitudes toward racial integration, a series of questions was asked both blacks and whites, beginning with one about the most general sentiments 
of the respondents: "Speaking in general terms, do you favor racial integration, total separation of the races, or something in between?" The word "separation" was used instead of "segregation" in order to make that choice more attractive to black respondents. Without this change, black respondents, remembering the long struggle against legal forms of segregation, would have been prompted to choose integration merely as an expression of support for the legitimate aspirations of the black community.

This general question evoked sharply different responses in the two racial communities, as Table 1 illustrates, and also uncovered the beginnings of an important shift in fundamental aspirations among blacks. In 1967, blacks were overwhelmingly in support of the ideal of integration, while whites were much more uncertain and divided on the issue. The majority of white respondents in 1967 chose the ambiguous "something in

TABLE 1

RESPONDENTS' COMMITMENT TO AN INTERRACIAL SOCIETY IN 1967 AND 1971, BY RACE (in percentages)

\begin{tabular}{|c|c|c|c|c|}
\hline & \multicolumn{2}{|c|}{ Whites } & \multicolumn{2}{|c|}{ Blacks } \\
\hline & 1967 & 1971 & 1967 & 1971 \\
\hline \multicolumn{5}{|c|}{ 1A. Attitudes toward the general ideal of integration } \\
\hline Integration & 24 & 27 & 88 & 68 \\
\hline In between & 57 & 54 & 11 & 29 \\
\hline Separation & 17 & 17 & 1 & 3 \\
\hline DK, NA & 2 & 2 & 0 & 0 \\
\hline Total & 100 & 100 & 100 & 100 \\
\hline \multicolumn{5}{|c|}{ 1B. Attitudes toward integration of the public schools } \\
\hline Favor school segregation & 30 & 34 & 2 & 8 \\
\hline $\begin{array}{l}\text { Favor integration, but } \\
\text { oppose demonstrations } \\
\text { which risk violence }\end{array}$ & 61 & 55 & 30 & 59 \\
\hline $\begin{array}{l}\text { Favor integration, and } \\
\text { support demonstrations } \\
\text { which risk violence }\end{array}$ & 9 & 4 & 66 & 29 \\
\hline DK, NA & 1 & 7 & 2 & 4 \\
\hline Total & $101^{a}$ & 100 & 100 & 100 \\
\hline
\end{tabular}

a. Total exceeds 100 because of rounding. 
between" option, with the remainder closely divided among supporters of "integration" and "separation." The attitudes of whites changed very little by 1971 , but during these four years support for integration in the black community declined by 20 percentage points, with the option of "something in between" increasing by 18 points, and "separation" by 2 points. Most surveys of opinion among blacks in the recent past have shown massive support for the ideal of racial integration, as did our 1967 survey (see Marx, 1969: 224-227 for a discussion of the most recent survey data; Campbell and Schuman, 1968: 15-19; Brink and Harris, 1967, also document this fact). Integration always has been a vaguely defined concept, but during the last thirty years it has remained one of the principal slogans of the civil rights movement, a term which summarized the ultimate goal of dignity and equality for black people. This clear sign of declining support for integration is evidence of the beginning of a new era in the history of American race relations.

On a more specific, policy level, the respondents were asked: "Some people say that white and [black] children" should go to the same schools; others feel that they will learn more and be happier in separate schools. What do you think?" If the respondent said he believed they should attend the same schools, the question continued with: "Do you agree or disagree with this statement: Demonstrations to protest segregation of schools are a good idea, even if a few people get hurt." The results of this question, displayed in Table $1 \mathrm{~B}$, showed marked differences between the two racial communities on this issue.

Among white respondents in 1967, 30\% believed that black and white children should attend separate schools. Almost $70 \%$ of the whites favored integration in the schools, but only $9 \%$ would be willing to tolerate possibly disruptive demonstrations to achieve the goal. Blacks in 1967 expressed massive commitment to the goal of integration. The depth of this commitment was revealed by the striking fact that $66 \%$ of the black respondents said they would support potentially violent demonstrations designed to achieve integration. When this same question was asked in 1971, the whites were less enthusiastic 
about school integration, but 59\% still supported the idea. The black community, however, had undergone a profound change which may have far-reaching political consequences. Although $88 \%$ of the black respondents still preferred school integration, only $29 \%$ were now ready to risk violence to achieve the goal, a drop of $37 \%$ from 1967 . There is still a commitment to the idea of integrated education, but no longer with the intensity and passion which once accompanied this demand. It is certainly significant that close to one-third of the 1971 black respondents remained willing to risk violence to achieve school integration, but broadly based community support for vigorous tactics of this kind to reach the goal of integration had definitely begun to evaporate.

The black community's commitment to the goal of racial integration seems to be waning, but in both 1967 and 1971, overwhelming majorities remained convinced that integrated educational facilities were desirable. The determination of blacks to achieve integration in the schools was declining, but this did not imply that separationist alternatives were necessarily gaining in favor. The preference of blacks for integration in education was duplicated in most other social spheres we investigated, including such sensitive problems as control over local businesses and the make-up of police patrols. ${ }^{10}$ However, integration had clearly lost its position with many as a top-priority goal. ${ }^{1}$

\section{DECENTRALIZATION OF THE SCHOOLS}

The brief recall campaigns and the flurry of legal activity which surrounded the school decentralization controversy in Detroit never resulted in broad, well-organized efforts to educate the general public. The conflict over the issue involved mostly community leaders, professional educators, and editorial writers on the city's newspapers. Because decentralization was not debated at length over several years, it is doubtful that the average citizens of the city were fully aware of the reasons why 
one plan might be preferred over another. Nevertheless, we found that respondents had opinions on this issue and were willing to express them. There were very few who responded with "don't know" or "can't say" when approached:

There's a lot of controversy these days in Detroit over the way the public schools should be organized. Some people believe that the schools will pay more attention to the needs of parents and students if each area in the city elects its own separate school board; others believe that the system would be more efficient and cheaper to operate if it remains under the control of a single, citywide school board. Which way would you prefer: separate area school boards or a single, citywide school board?

Both racial groups displayed, in their answers to this question, a preference for the older, centralized system, even though decentralization plans then were being implemented. The initiative for decentralization arose from the black community, but, as Table 2 illustrates, there was more support for the idea among whites than among blacks.

Support for school decentralization came from minorities in both racial groups, but from an important, strategically located minority in the black community. The plan had been proposed originally by members of the black political leadership and was supported mostly by the upper-status, politically active elements in the community, as demonstrated in Table 3 , where a favorable attitude toward decentralization is correlated with level of education. The relationship between educational level

TABLE 2

RESPONDENTS' ATTITUDES TOWARD SCHOOL DECENTRALIZATION IN 1971, BY RACE (in percentages)

\begin{tabular}{lcc}
\hline & \multicolumn{2}{c}{ Racial Group } \\
\cline { 2 - 3 } & Whites & Blacks \\
\hline Single citywide board & 50 & 64 \\
Decentralized boards & 37 & 29 \\
Don't know/No answer & 13 & 7 \\
\multicolumn{1}{c}{ Total } & 100 & 100 \\
\hline
\end{tabular}


TABLE 3

PERCENTAGES OF RESPONDENTS SUPPORTING DECENTRALIZED SCHOOL BOARDS IN 1971 ACCORDING TO THEIR EDUCATIONAL LEVEL, BY RACE

\begin{tabular}{|c|c|c|c|c|}
\hline \multirow[b]{2}{*}{ Educational Level } & \multicolumn{4}{|c|}{ Supporting Decentralization } \\
\hline & Whites & (n) & Blacks & (n) \\
\hline Grade school & $40 \%$ & (63) & $17 \%$ & (36) \\
\hline Some high school & $48 \%$ & (48) & $27 \%$ & (37) \\
\hline $\begin{array}{l}\text { Some high school plus noncollege } \\
\text { training }\end{array}$ & $50 \%$ & (24) & $27 \%$ & (15) \\
\hline High school graduate & $51 \%$ & $(65)$ & $33 \%$ & (39) \\
\hline $\begin{array}{l}\text { High school graduate plus } \\
\text { noncollege training }\end{array}$ & $46 \%$ & $(35)$ & $45 \%$ & (20) \\
\hline Some college and above & $36 \%$ & $(114)$ & $57 \%$ & (14) \\
\hline & \multicolumn{2}{|c|}{ Gamma $=.07$} & \multicolumn{2}{|c|}{ Gamma $=-.36$} \\
\hline
\end{tabular}

and a preference for decentralization is strong (gamma of -.36). This kind of support is especially important in a controversy of this sort. The educated members of the community are likely to take greater interest in a dispute over the school system, and are more likely to be listened to by political leaders and the professionals who operate the system. Many middle-class blacks were anxious to employ the schools as instruments of reform in which black students would gain a more affirmative identity and a deeper knowledge of black culture. The rising concern with the promotion of black pride and racial unity has begun to dominate the thinking of this group. They were increasingly convinced that decentralization would further these goals and were less concerned over its impact on the achievement of racial integration.

Black supporters of decentralization were exceedingly distrustful of government in general. There was a very strong relationship (gamma of .52) between the general level of trust in government, ${ }^{12}$ measured by a modified version of the Survey Research Center's political trust scale and support for decentralization. Those low in political trust were likely to advocate the creation of smaller, neighborhood school boards to replace or supplement the citywide board. These distrustful blacks hoped 
to gain greater access for the entire community to the educational leadership under the new plan and hoped to stop abuses they believed were being perpetrated against black students by the allegedly insensitive and unresponsive centralized school administration.

Supporters of school decentralization in the white community came disproportionately from working-class neighborhoods, especially those in danger of being integrated as the black population expanded. In Table 3, the highest levels of support for decentralization came from those who had not completed high school, but had some additional (usually technical) training and from high school graduates. There is a fifteen percentage point difference in support for decentralization between those who have been to college and high school graduates.

Table 4 indicates the complex relationship between attitudes toward integration and support for school decentralization. Those in both communities who favored integration were more likely to desire a single, citywide school board. In order to check whether decentralization was merely a code word for racial separation, respondents who selected separate area school boards as their preferred alternative were asked: "Which do you prefer, integrated districts which contain approximately equal numbers of [black] and white children, or separate districts for [blacks] and whites?" Those who favored general integration were more likely to prefer integrated, decentralized districts. More noteworthy, blacks were consistently more opposed than whites to the idea of racially separated school districts, no matter what their general views on integration. For the blacks, community control did not necessarily imply separate schools, although those opposed to general integration were more favorable to the idea of decentralization. For separationist whites, on the other hand, the notions of community control and segregated schools tended to join neatly. In rejecting the school board's plan, the separationists were not necessarily rejecting decentralization. 
TABLE 4

SUPPORT FOR SCHOOL DECENTRALIZATION land integration within decentralized districts) BY GENERAL ATTITUDE TOWARD RACIAL INTEGRATION IN 1971, BY RACE (in percentages)

\begin{tabular}{|c|c|c|c|}
\hline & \multicolumn{3}{|c|}{ General Attitude Toward Racial Integration } \\
\hline & Integration & In Between & Separation \\
\hline \multicolumn{4}{|l|}{ Whites } \\
\hline Favor single citywide district & 68 & 61 & 46 \\
\hline $\begin{array}{l}\text { Favor decentralized integrated } \\
\text { districts }\end{array}$ & 28 & 19 & 2 \\
\hline $\begin{array}{l}\text { Favor decentralized separate } \\
\text { districts }\end{array}$ & 3 & 18 & 52 \\
\hline Total & $\begin{array}{c}100 \\
(n=92)\end{array}$ & $\begin{array}{c}99 b \\
(n=176)\end{array}$ & $\begin{array}{c}100 \\
(n=48)\end{array}$ \\
\hline \multicolumn{4}{|l|}{ Blacks } \\
\hline $\begin{array}{l}\text { Favor single citywide district } \\
\text { Favor decentralized integrated } \\
\text { districts }\end{array}$ & $\begin{array}{l}75 \\
24\end{array}$ & $\begin{array}{l}59 \\
33\end{array}$ & $(3)^{a}$ \\
\hline $\begin{array}{l}\text { Favor decentralized separate } \\
\text { districts }\end{array}$ & 1 & 9 & $(2)^{a}$ \\
\hline Total & $\begin{array}{c}100 \\
(n=108)\end{array}$ & $\begin{array}{c}101^{b} \\
(n=46)\end{array}$ & $\begin{array}{c}a \\
(n=5)\end{array}$ \\
\hline Percentages are down. & & & \\
\hline
\end{tabular}

a. N of 5 or less.

b. Totals not 100 because of rounding.

\section{THE RECALL ELECTION}

Detroit's controversy over school decentralization took place, for the most part, in the hearing rooms of the board of education, the state legislature, and the courts. Debates between lawyers and professional educators over technicalities attracted little general interest, and information about the proceedings was not easy to understand. There was only one point in the course of the dispute when public opinion might have been directly brought to bear, and that was the motion to recall the members of the school board who had supported the decentralization plan which encouraged racial integration. 
About $35 \%$ of the total city electorate voted in the August 4, 1970 , primary election when the recall appeared on the ballot. Voters were given just four days' notice that the recall would be conducted, and a large number of ballots were left blank on this issue, evidence of the public's lack of knowledge and its confusion and uncertainty over the issues at stake. The recall had been instigated by groups in the white community who objected to increased racial integration in the schools, and when the way was cleared by the courts to add the motion to the primary ballot, these groups immediately went in to action to inform their sympathizers and get them to the polls. There were no comparable groups as well organized and as intensely interested in this issue in the black community. Several small black nationalist or separatist groups had spoken out against the integrationist aspects of the proposed decentralization. More important, the labor unions, the NAACP, and other civil rights groups were not prepared to mobilize their followers to defeat the recall. Even if prepared, it seems clear that their task would have been difficult given the general lack of enthusiasm for decentralization and waning interest in the vigorous pursuit of integration. Intensity, organization, and commitment were all on the side of those who supported the recall motion.

This disparity was reflected in the results of our survey, taken several months after the recall election was over. When respondents were asked if they remembered the recall election, whites were much more likely than blacks to say that they did. Table 5 shows that a greater percentage of whites at almost all educational levels claimed they remembered the controversy. This difference between the races is most apparent among the best-educated members of the two communities. Over $80 \%$ of whites with college training, for example, claim to have remembered the event, compared to just over $60 \%$ of comparable blacks.

White were not simply reacting against the idea of decentralizing the schools in the recall, but rather against the threat of increased racial integration. Among whites, there was a correlation of (gamma) .43 between preferences for racially segregated 
TABLE 5

\section{PERCENTAGES OF RESPONDENTS AT VARIOUS EDUCATIONAL LEVELS REMEMBERING THE RECALL ELECTION OF AUGUST 4, 1970, BY RACE}

\begin{tabular}{|c|c|c|c|c|}
\hline \multirow[b]{2}{*}{ Educational Level } & \multicolumn{4}{|c|}{ Remembering Recall } \\
\hline & Whites & (n) & Blacks & (n) \\
\hline Grade school & $38 \%$ & (63) & $45 \%$ & (36) \\
\hline Some high school & $44 \%$ & (48) & $34 \%$ & (37) \\
\hline $\begin{array}{l}\text { Some high school plus noncollege } \\
\text { training }\end{array}$ & $84 \%$ & (24) & $60 \%$ & (15) \\
\hline High school graduate & $70 \%$ & (65) & $44 \%$ & (39) \\
\hline $\begin{array}{l}\text { High school graduate plus } \\
\text { noncollege training }\end{array}$ & $86 \%$ & (35) & $42 \%$ & $(20)$ \\
\hline Some college and above & $82 \%$ & (114) & $63 \%$ & (14) \\
\hline & \multicolumn{2}{|c|}{ Gamma $=-.52$} & \multicolumn{2}{|c|}{ Gamma $=-.10$} \\
\hline
\end{tabular}

school districts and support for the recall motion. It seems clear that many whites saw a vote for the recall as a vote for the maintenance of segregation.

The apparent apathy over the recall motion in the black community is more difficult to explain. The established black groups and civil rights organizations were caught by surprise when the court gave its last-minute approval to the recall, and almost no campaign against the motion was mounted. No citizens' committee or ad hoc coalition supporting integrated decentralization plans had sprung up prior to the recall, however-an indication that the idea had not developed deep roots in the black community. The politically active, middleclass black leadership did not carry on the vigorous campaign of support which the integrationist school board members obviously had expected. One must speculate about the reasons for the black leadership's relative inactivity, but the principal causes probably lie in their developing ambivalence about the ideal of racial integration. There is support among upper-status blacks for increased neighorhood control over the schools, but their desire was to use this increased influence primarily to promote black culture and increased self-esteem among black students. This new emphasis conflicted somewhat with the drive of the 
school board majority to use the doctrine of neighborhood control to achieve racial integration, and although most blacks have not abandoned their support of integration, our data show that they are beginning to lose the passionate sense of commitment to the ideal which once existed. This ambivalence and the lack of support for decentralization among lower-status blacks probably restrained black leaders from taking action to mobilize the community in favor of the original integrationist decentralization plans. Massive support for integrated schools still existed in the black community, as our survey showed, but black leaders lacked the will, the commitment, and perhaps even the ability, to bring this support into action. The organizational initiative passed to those in the white community who held conservative views on school integration. ${ }^{13}$

\section{SUMMARY AND CONCLUSIONS}

The struggle over decentralization of Detroit's school system began in the Michigan state legislature with little fanfare or dispute. The motives of the original proponents were unambiguous. Decentralization in cities was a popular reform measure at the time, and most legislators believed the reorganization might possibly improve the system, and, in any case, was unlikely to do any harm. Once the mandate to decentralize was given to the existing board of education, however, boundaries of the new districts had to be drawn, and it was impossible to ignore the potentially explosive issue of racial balance in the schools. Rather than dodge this issue, the school board decided to use decentralization as a tool for breaking down existing racial barriers. What began as an effort to improve the representativeness or responsiveness of the city's educational bureaucracy soon became also a new method to encourage racial integration.

When the original, integrationist decentralization plan was made public, it stimulated a strong reaction in white neighborhoods where schools were virtually segregated. New organizations sprang into being in these neighborhoods and a deter- 
mined counterattack was mounted in the state legislature, the courts, and through the recall petition which eventually was successful in preventing any changes in racial balances in the schools. The burning issues of racial equality and discrimination had been forced to the center of the dispute, overshadowing the original questions of political and administrative organization and bureaucratic rigidity, and creating a wholly different balance of power for educational decision-making.

As the scope of the conflict widened and the central issues changed, black leaders either were not able or were unwilling to mobilize their followers in support of the integrationist, decentralization plan. Our studies indicate that support for integration is beginning to decline in the black community, especially among members of the middle class, whose organizational skills were required in these circumstances. Even though there remained massive support for integration within the black community, it could not be given expression without the energies and resources of leaders skilled in the task of mobilization.

The notion of decentralization, on the other hand, did not have majority support in either racial community. Questions of administrative and political organization, by themselves, are not the kinds of issues likely to arouse intense concern among average citizens, but for a sizable group of whites, decentralization was preferable because it was seen as a means to prevent racial integration. Among blacks, the idea appealed most strongly to the middle class, especially to those devoted to promoting black culture and a new sense of self-respect, but was not the kind of issue which could be used to bring large numbers of black voters to the polls to oppose the recall. Many black leaders wanted decentralization, but were unsure about integration; such uncertainty did not supply the kind of stimulation for action which fear of increased racial integration gave many whites.

Policy-making for urban areas of ten takes place in legislative bodies or government agencies far from the cities themselves. The complex institutions of federalism, and the many legally 
autonomous, specialized decision-making forums like the educational system, allow little knowledge or concern for the desires of the passive majority. The conflict over school decentralization in Detroit started with few participants, but once it began to grow, the expansion was exceedingly uneven, with one side, the segregationist whites, rapidly gaining adherents and confidence, while black leaders remained divided and disorganized. The efforts of the whites were facilitated in this case by legal delays which kept their opponents off balance, and, ironically, by the use of a recall petition, a reform of the Progressive era designed to encourage governmental responsiveness to majority will.

Little effort was made, either by the original sponsors of decentralization or the school board members who decided to use the plan to further integration, to gain public understanding or build majority support for these proposals before they were introduced. Indeed, that would have been a formidable task, since few established organizations or institutions exist in the city, especially in the area of education, which might easily have been used to mobilize the public support needed on these issues. There is little communication between elected representatives and their constituents, so that of ficials are never sure which of many competing voices actually represents the majority will. In most cases, the system requires those who object to policies adopted either by educational professionals or elected representatives to create ad hoc organizations and stage large-scale protests if they hope to see policies changed. Officials in a system of this kind are not encouraged to take serious account of any interests which are not already organized, present in the political arena, and expressing active concern at the time decisions are made. The possibility always exists that "potential groups" might be stimulated into action by some outrageous decision, but since public awareness of government actions is low, and the costs of organizing a protest is extremely high, the possibility of decisions being overturned in most cases is decidedly remote. In the Detroit decentralization dispute, protesting white citizens were passionately 
concerned and united in their cause; they not only mounted a protest, but were successful in changing the offending policies, two equally rare occurrences. ${ }^{14}$

The political system produced an outcome in the Detroit case pleasing only to a minority. Not only were the integrationist school board members recalled, but a system which encouraged racial separation was established, somewhat moderated by addition of a modified "freedom-of-choice" plan of the kind once popular in southern cities. Our surveys reveal considerable ambivalence among both whites and blacks about terms like decentralization and integration, and it is hard to determine the depth and sincerity of their commitment to these ideals. There are several indications, for example, that the support for school integration expressed by many whites does not imply a willingness to take any risks or make any sacrifices. Even allowing for these reservations, however, the evidence indicates that the preference of a majority of each race was a centralized, integrated school system. The political system produced for them, instead, a system which was decentralized and segregated.

\section{NOTES}

1. This movement has produced a large volume of literature, but the following will provide good summaries of the aims and justifications of decentralization: Altshuler (1970), Gittell (1971), Rogers (1968); see also Cunningham (1970).

2. Another study somewhat similar to this one which deals with the school decentralization controversy in New York is Gittell (1971).

3. We will refer to our data as covering the city, but the study area included, as well, Highland Park and Hamtramck, two small cities completely surrounded by Detroit, and the Grosse Pointes, a cluster of small, upper-class suburbs along Detroit's northeastern border.

4. Approximately 3,100 of 290,000 public school students would have been immediately affected and then only at the high school level.

5. The opponents of the recall were largely inactive because of a belief that the issue would never be on the ballot and a general apathy about the whole matter among many of the groups which usually support efforts at racial integration.

6. As of $1970,63 \%$ of the students in the public schools of Detroit were black, $42 \%$ of the teachers, and $26 \%$ of the administrators. The latter two figures compare very favorably with other large American cities. 
7. This phrase was used by Moore and Johnston (1971: 428). For a discussion of the campaign, see also Grant (1971: 74-75).

8. Vote fatigue is a common problem for black voters in municipal and state elections. For studies in other settings, see Walker $(1966,1963)$.

9. Early in the interview, black respondents were asked, "One hears a lot of different terms used these days to identify race. What term do you prefer when talking about yourself?" Whatever term the respondent gave was used consistently throughout the interview. For white respondents, the work "Negro" was used in all cases.

10. Data on this subject from a survey done in Detroit in 1968 were reported in Aberbach and Walker (1970a). More extensive analysis of 1971 data will appear in Aberbach and Walker (forthcoming).

11. Further evidence for this can be found in answers given to a question in the 1971 survey, focused on housing, which attempted to prove the issue of priority more directly when we asked "Which do you think is more important now-to build more and better housing in and around areas where blacks already live or to build integrated housing for blacks in other parts of the city and suburbs?" Only $17 \%$ of the whites mentioned integrated housing, and, more importantly, only $37 \%$ of the blacks chose that option.

12. The questions in the political trust index focused on the national and the local level of government (see Aberbach and Walker, 1970b: 1203) for a description of the measure.

13. In the elections for the eight new regional boards held in November 1970, whites won control of six of these boards, blacks of the remaining two. Many white segregationists were elected, while most of the successful black candidates were integrationists. The central board previously had three black members out of a total membership of seven; the central board has three blacks out of thirteen. Only thirteen blacks were elected to forty-three seats on all the boards. The Detroit Free Press (1970d) commented, "Detroit voters have elected the city's most conservative school board in at least six years."

14. The use of the concept of "the scope of the conflict" betrays our intellectual debt to Schattschneider's (1960) brilliant book. We have also gained special insights from Gamson (1968a, 1968b), and the voluminous literature surrounding the group and the pluralist theories of the political process.

\section{REFERENCES}

ABERBACH, J. D. and J. L. WALKER (forthcoming) Race in the City. Boston: Little, Brown.

--- (1970a) "The attitudes of blacks and whites toward city services: implications for public policy," pp. 519-538 in J. P. Crecine (ed.) Financing the Metropolis: Public Policy in Urban Economies. Beverly Hills: Sage Pubns. -- (1970b) "Political trust and racial ideology." Amer. Pol. Sci. Rev. 64. ALTSHULER, A. A. (1970) Community Control. New York: Pegasus. 
BRINK, W. and L. HARRIS (1967) Black and White: A Study of U.S. Racial Attitudes Today. New York: Simon \& Schuster.

CAMPBELL, A. and H. SCHUMAN (1968) Racial Attitudes in Fifteen American Cities. Ann Arbor, Mich.: Institute for Social Research.

CUNNINGHAM, L. L. (1970) "Educational governance and policy making in large cities." Public Administration Rev. (July/August): 333-339.

Detroit Free Press (1970a) August 2: 18A.

$--(1970 \mathrm{~b})$ August 5: 3A.

--- (1970c) August 6: 6A. (1970d) November 7: 12A.

GAMSON, W. A. (1968a) "Stable unrepresentation in American society." Amer. Behavioral Scientist (November/December): 15-21.

-- (1968b) Power and Discontent. Homwood, Ill.: Dorsey.

GITTELL, M. (1971) "Education: the decentralization-community control controversy," pp. 134-163 in J. Bellush and S. M. David (eds.) Race and Politics in New York City. New York: Praeger.

GRANT, W. (1971) "Community control vs. school integration in Detroit." Public Interest (Summer): 62-79.

Magnet School Plan (1971) "Highlights of the Magnet School Plan: what every school employee will want to know." Progress Report 5, April 23.

MARX, G. T. (1969) Protest and Prejudice. New York: Harper.

Michigan Chronicle (1970) "Too much black power real basis of recall." August 15: 8.

MOORE, C. H. and R. E. JOHNSTON (1971) "School decentralization community control and the politics of public education." Urban Affairs Q. (June).

New Detroit Now (1970) "The eight regions of decentralization: some answers." Volume 1 (December).

ROGERS, D. (1968) 110 Livingston Street. New York: Random House.

SCHATTSCHNEIDER, E. E. (1960) The Semi-Sovereign People. New York: Holt, Rinehart \& Winston.

WALKER, J. L. (1966) "Ballot forms and voter fatigue: an analysis of the office block and party column ballots." Midwest J. of Pol. Sci. (November): 448-463.

--- (1963) "Negro voting in Atlanta: 1953-1961." Phylon (Winter): 379-386. 